\title{
THE FUNCTION AND GENESIS OF THE MUSICAL INSTRUMENT "TROMBITA” WITH SPECIAL FOCUS ON THE HUTSUL REGION
}

\author{
JUSTYNA CZĄSTKA-KŁAPYTA
}

\begin{abstract}
The function and genesis of the musical instrument "trombita" with special focus on the Hutsul region

The question of the origins and cultural impact of music cultivated by the Vlachs on the Carpathian music heritage is relatively poorly examined in the previous literature. This is mostly because of insufficient ethno-historical data sources, the short time of detailed documentation of rural folklore, and the collective character of music, which often goes beyond the boundaries of nationality. Most of the previous works dealing with the problem of the Vlachs' impact on the Carpathian music folklore were presented as a short comments.

One of the still unresolved issues is the origin of the shepard's trumpets (trombitas, horns) in the territory of the Carpathians. It is widely known as "trombita" (the Western Carpathians, Poland), „trembita” (the Ukrainian Carpathians), „trubyela”, „bucium”, and „tulnic” (Romania). They are among the wide type of instruments known by ancient Slavs. According to principal hypothesis these instruments originated in Asia and were transferred to the Carpathian Mountains by migrating Indo-European peoples. Alternative hypothesis suggests that "trembita" was brought to the Carpathians by migrating Roman legionaries, who used this instrument for the signalling functions. The occurrence of these instruments coincides clearly with the area of the Wallachian settlement, allowing the presupposition that the spread of trombita in the Carpathians is linked with the Wallachian colonisation.

The problems outlined in this article concerns the spatial distribution and typology of Carpathian trumpets as well as their functions with special focus on the Hutsul region (the Eastern Carpathians, Ukraine), where they still perform important ritual and magical functions, mainly during carolling. The analysis of the function of trombita in this context allows to define its place and importance in the pastoral tradition.
\end{abstract}

Author: Justyna Cząstka-Kłapyta, Polskie Towarzystwo Ludoznawcze, oddział Kraków (Polish Ethnological Society, Krakow branch), e-mail: hucul.klapytki@gmail.com

Keywords: ethnomusicology, ethnology, Hutsul region, trombita, Vlachs.

Balcanica Posnaniensia. Acta et studia, XXIII, Poznań 2016, Wydawnictwo Instytutu Historii UAM, pp.187196, ISBN 978-83-65663-26-9, ISSN 0239-4278. English text with a summary in English.

doi.org/10.14746/bp.2016.23.13

\section{INTRODUCTION}

The problems of the origin, characteristics and influence of music cultivated by the Vlachs are rarely analyzed and have not been discussed in any separate studies. The main cause of this state of affairs are insufficient sources, the late documentation 
period of the rural folklore, the common and shared character of musical phenomena that often goes beyond the boundaries of nationality. Most references to the Vlach influence in the music of the Carpathian Mountains and its characteristics ${ }^{1}$ were mentioned in studies of various (specialist or popular). Several works involving cultural areas of the Western and Eastern Carpathians (Poland, Ukraine, Slovakia, Romania) should be mentioned here. They are written by Włodzimierz Kotoński $(1953,1954)^{2}$, Adolf Chybiński (1961) $)^{3}$, Aurelia Domaradzka-Barbier (2001) and Jozef Kresánek $(1997)^{5}$. The problem of the influence of Vlach-Ruthenian music of the Carpathians (including instruments, scales, song melodies) was undertaken by the author of this article with particular emphasis on the musical culture of the Ruthenians from Ostrunia $(2008)^{6}$.

The musical instruments are most profoundly analyzed part of the musical folklore of the Carpathians. However, most of these works emphasize the organological issues (history, structure, ownership of the instrument), and ignore the the role of musical instruments in the material and spiritual culture.. The musical instrument used most frequently by the mountain, shepherd community of the Vlach origin is called trombita. The question of the precise function and appearance of this instrument on the territory of the Carpathians remains unsolved. Research devoted to trombita was conducted by such Romanian, Polish and Slovak scholars as Aleksandru Tiberiu (1980) ${ }^{7}$, Ion Chelcea $(1989)^{8}$, Adolf Chybiński ${ }^{9}$, Alojzy Kopoczek ${ }^{10}$, Alicja Elscheková ${ }^{11}$, Oskar Elschek $^{12}$ and a Ukrainian researcher Bogdan Jaremko ${ }^{13}$. A Russian researcher Ihor Macijewski investigated on the example of trembita from Hutsul region and focused

\footnotetext{
1 The regions where the Vlachs live (Greece, Macedonia, Albania, Romania). However, the problem of the advancement research on the musical culture of these regions requires a deeper analysis.

2 W. Kotoński, Uwagi o muzyce Podhala „Muzyka”, 1953, vol. 5-12. W. Kotoński, Uwagi o muzyce Podhala. „Muzyka”, 1954, 5-6.

3 A. Chybiński, O Polskiej muzyce ludowej, Warszawa 1961.

${ }^{4}$ A.Domaradzka-Barbier, Praktyka muzyczna górali śląskich: analiza śpiewów beskidzkich i próba wyodrębnienia modelu struktury melodycznej, „Muzyka” 2001, no 3, p. 51-67.

5 J. Kresánek, Slovenská l’udová pieseň zo stanoviska hudobného, Bratislava 1997.

${ }^{6}$ J. Cząstka-Kłapyta, Wpływy wołoskie w folklorze muzycznym Karpat ze szczególnym uwzględnieniem rusińskiej wsi Ostrunia - przyczynek do rozważań, in: Wołoskie Dziedzictwo Karpat, Czeski Cieszyn 2008.

${ }^{7}$ A. Tiberiu, Romanian Folk Music, Bucharest 1980.

8 T. Alexandru, Romanian folk music, Musical publishing house, Bucharest 1980; I. Chelcea, Consideraţii etnografice cu privire la bucium, tulnic şi trâmbita, "Revista de Etnografie şi Folclor", 1989, vol. 34-1, p. 59-65; Tradicijska Narodna Glazbala Jugoslavije, uredio J. Bezić, M. Gavazzi, M. Jakelić, P. Mihanović, Zagreb 1975.

${ }^{9}$ A. Chybiński, O Polskiej muzyce ludowej, Warszawa 1961.

${ }^{10}$ A. Kopoczek, Ludowe instrumenty muzyczne polskiego obszaru karpackiego, Rzeszów 1996.

11 A. Elscheková, Stratigraphische Probleme der Volksmusik in den Karpaten und auf dem Balkan, Bratislva 1981.

12 O. Elschek, Slovenské l'udové pištály a d'alšie aerofony, Bratislava 1991.

13 Б. Яремко, Трембита как феномен древней гуцульской традиционной культуры, Вопросы инструментоведения, выл. 5, ч. 1, ред. Г. И. Благодатов, Санкт-Петербург 2004, р. 69-74.
} 
on the questions related to semantic system of the sonic $\operatorname{codes}^{14}$. Issues related to the musical and cultural function of trembita ${ }^{15}$ during the carolling in the Hutsul region was studied by Justyna Cząstka-Kłapyta ${ }^{16}$. The conclusions presented in the article derived from these studies ${ }^{17}$ will be the basis for determining the overall cultural function of trembita.

The beginning of the disappearance of the musical shepherd culture in the Carpathian Mountains began at the end of the 19th century, when pastoral economy started to decline ${ }^{18}$. At the same time the ability to understand the old magical and communication functions of many musical instruments (i.e. trombita), songs and dances decreased $^{19}$. Therefore, in this article, emphasis will be put on the Hutsul region (Ukraine, Eastern Carpathians), where the ritual and magical function of trembita survived. Even though trombita is not in use any more during pasturage, it still fulfills ceremonial functions as an instrument which accompanies funeral rites and Christmas carolling.

\section{GENESIS}

Trombitas belong to instruments known in the culture of the Slavs which for centuries used many pipe-shaped aerophones (wind instruments). This fact is proven by archaeological findings, as well as by different kinds of trumpets made of wood or bark, widespread among the Slavic peoples. However, trembita varieties found in the Carpathians differ greatly in design from other similar varieties of instruments (e.g.: ligawka - a kind of a wooden horn, bazuna - Kashubian alphorn), which might indicate their separate origins. The existence of aerophones among the Slavs is also proven by the analysis of the lexical names of these instruments: duda, piščal, sopélb, svirélb, troba i rogi $i^{20}$. However, aside from the issue of the origins of these instruments, they were used by the vast majority of pastoral peoples, also of non-Slavic origin. Long wooden trumpets ${ }^{21}$, which differed from the construction of the Carpathian ones, were also found outside the Slavic world, in the areas inhabited by the Volga

\footnotetext{
14 I. Мацієвський, Музичні інструменти гуцулів, ред. Й. Д. Колесник, Винниця 2012, pp. 463.

15 Trembita - the name of the instrument functioning among the Hutsuls.

16 J. Cząstka-Kłapyta, Kolędowanie na Huculszczyźnie, Kraków 2014, pp. 560.

17 The research was carried out in 2008-2011 in the villages: Bereżnica, Bukowiec, Kryvorivnia, Jasieniowa, Zamagura, Krasnoila, Hołowy, Verkhovyna and Ilci.

18 J. Cząstka-Kłapyta, Muzyczna Kultura Pasterska, in: Pasterstwo w Karpatach. Tradycja $i$ Wspótczesność, M. Kiereś, B. Rosiek et al. (ed.), Warszawa 2013, p. 57

${ }^{19}$ L. Leng, Zur Klassifikation der aerophonen Muikinstrumente im Gebiet der Karpaten und des Balkans, in: Stratigraphische probleme., p. 259.

${ }^{20}$ W. Boryś, Kultura muzyczna dawnych Stowian w świetle słownictwa, in: Dzieje Stowian w świetle leksyki. Red. J. Rusek, W. Boryś, L. Bednarczuk, Kraków 2002, p. 87.

21 The name is not encountered in the Hutsul region. It belongs to the general Slavic words of foreign origin, which were used for similar instruments; K. Moszyński, Kultura Ludowa Słowian, cz. II, Warszawa 1968, p. 582.
} 
Finns (Cheremis), as well as in Latvia, Lithuania, Germany, Scandinavia, Scotland, and in the area of the Pyrenees and the Alps ${ }^{22}$.

It is difficult to determine today the ways in which this instrument penetrated the Carpathians, but probably it was already known before the arrival of the Vlach shepherds ${ }^{23}$. There is a hypothesis that trembita got into Europe from Asia via migrating Indo-European peoples. The modern range of the occurrence of the instruments which resemble trombita reaches in Asia the territories on the Amur River and northern India ${ }^{24}$. Trembita could arrive in the Carpathian Mountains via the Imperial Roman army, which used this instrument for signaling. It is also possible that the Dacians, whose culture could be marked by the Roman influence, played an important role in the transfer of the instrument. In ancient Rome a very similar type of instrument - buccina - was used for war purposes. A similar name - bucium ${ }^{25}-$ has been attributed to the Romanian variant of trombita. The area of the occurrence of this instrument coincides clearly with the range of the Vlach colonization, which allows one to assume that the Vlachs played an important role in the dissemination of trombita throughout the Carpathians. It is also possible that the oldest core not only of the Hutsul, but the entire Carpathian, and even beyond the Carpathian tradition of playing this instrument and other aerofons originates from the pastoral tradition - the Vlach one or of the older origin. Similar ways of using trombita and its varieties do not find their counterparts outside the mountain regions of Poland, Ukraine, Romania, Bulgaria, Slovakia, Hungary, Slovenia, Scandinavia and the Balkans ${ }^{26}$.

\section{THE CHARACTERISTICS OF THE INSTRUMENT}

Trembita belongs to aerophones (wind instruments), originally wooden, but later also metal ones. Aerophones occupy an important place in the musical culture of the Balkans and Carpathians. However, compared with the Balkan tradition, it was in the Carpathians where they were the dominant group of instruments ${ }^{27}$. Trembita is an instrument widely used throughout the whole of the Carpathians. It functions under different names: in Poland and Slovakia under the name trembita, in the Silesian Beskid as sałaska trumpet, in Moravian Wallachia as salašovka ${ }^{28}$ or hlasnica ${ }^{29}$ : trambita (Bucovina), tranghita (Maramures, Oas), bucium, tulnic (Apuseni Moutians). In

${ }^{22}$ K. Moszyński, op.cit, p. 589.

${ }^{23}$ A. Chybiński, op.cit, p. 344.

${ }^{24}$ Ibidem.

${ }^{25}$ L. Winniczuk, Ludzie, zwyczaje i obyczaje starożytnej Grecji i Rzymu, Warszawa 2004.

${ }^{26} \mathrm{http}$ ://www.eliznik.org.uk/RomaniaMusic/bucium.htm: Eliznik, Bucium, [accessed on 4.11.2016].

${ }^{27}$ L. Leng, Zur Klassifikation der aerophonen Muikinstrumente im Gebiet der Karpaten und des Balkans, in: Stratigraphische probleme der Volksmusik in den Karpaten und auf dem Balkan, Bratislva 1981, p. 259.

${ }^{28}$ L. Kunz, Nástroje lidové hudby v Ćechách, na Moravě a ve Slezsku, vol. 4, Rožnov 2010, p. 697.

${ }^{29}$ L. Kunz, Nástroje lidové hudby v Ćechách, na Moravě a ve Slezsku, vol. 2, Rožnov 2009, p. 367. 
Serbia and Croatia it is known under the name of bušen (Serbia), or trubyela, trom$b i t a^{30}$. Its variants also appear outside the Carpathians, in Lithuania (truba) or in the mountainous regions of Scandinavia (luur) and Switzerland (Alphorn) $)^{31}$.

This instrument is made of two wooden halves made of spruce severed in the length of the instrument and glued with boiled resin. In the Hutsul region trembita was usually made of wood from the trees injured by lightning (hromovytsia) ${ }^{32}$. Two halves made of wood form a narrow conical tube, expanding gradually from the lower to the upper outlet. Its length can range from 1.5 to 4 meters. The trombita made by highlanders from Beskid Śląski and the Boyko region in Ukraine reach the most impressive sizes). In turn the trombitas from Podhale and Limanowa and Piwniczna (Poland) are the shorter ones. Trombitas length of 1-2 meters are common over the entire Slovakia ${ }^{33}$. The lighter trembita of 3 or 5 meter long comes from the Hutsul region; it can be hold by one person, while the trombitas from Beskid Zachodni must be hold by two. Trombita, as well as other pastoral instruments, could be played only by males, who usually had solo performances A peculiar phenomenon in the mentioned context is a tradition which can be observed in the Apuşeni Mountains in Romania (Ţara Moţilor), where this instrument (tulnik) is played jointly by men and women alike. Common playing is practiced also among the Hutsuls during the pasturage. Today, it is played usually by men during Christmas caroling, and it's often accompanied by horns (rih).

\section{THE USE OF THE INSTRUMENT AND ITS FUNCTION}

Trombita is an important component of the pastoral culture of the Vlach origin communities. This is the cause of its wide use in the pastoral economy. It was used in such rites as: funerals (Ukraine - the Hutsul and Boyko regions, and Romania Bucovina, Oaş, Maramureş), Christmas caroling (the Hutsul region ) and weddings the Hutsul region). It was used during the departures to seasonal pastures, stay in the shepherd's hut, and the ceremony which ended pasturage, as well as during hunting $^{34}$. Until this day, shepherds use this instrument on the occasion of grazing sheep in the mountains of Romania (Bukovina, Rodna and the Marmarosh Mountains) and in the Balkans as well as in the region inhabited by Rusyns at the Romanian border the (Marmarosh Mountains in the Carpathians). In turn, the Hutsul trembitas came out of use on mountain meadows after World War II. In the Western Carpathians the practice of playing trombitas survived until the 70 s of the 20th century, which is longer

\footnotetext{
30 J. Cząstka-Kłapyta, Kolędowanie, p. 436.

${ }^{31} \mathrm{http} / / /$ www.eliznik.org.uk/RomaniaMusic/bucium.htm, [accessed on 4.11.2016].

${ }^{32}$ I. Macijewski, Huculska trembita, in: Huculszczyzna, jej kultura i badacze. Międzynarodowa konferencja naukowa w ramach Festiwalu Huculskiego „Za głosem trembity” 2006, J. Stęszewski, J. CząstkaKłapyta (ed.), Kraków 2008, p. 77.

${ }^{33}$ O. Elschek, Slovenské l'udové pištály, p. 49.

34 Personal field research, Werchowyna 2010: Informatnt M. Iliuk (ur. 1967 Zamagura), Michajło Tafijczuk (born 1939 Bukowiec).
} 
than in Podhale, where it functioned during the pastoral rites until the beginning of the 20th ${ }^{\text {th }}$ century. In Moravian Wallachia its disappearance dated back to the years $1860-1880^{35}$.

Among the Hutsuls trembita playing occurred during the time related to the awakening of all life in nature, fertility and harvest, precisely on the day of Saint George (Jurij-April 23 according to the Orthodox calendar, in the 20th century its May 6), and it lasted until the day of Saint Dmytro (October 26 / November 8) which was already closer to the winter period ${ }^{36}$. In contrast, year-round, even in winter, trembita could be played only during funerals. The mournful tunes were played right after death $\mathrm{d}$, before the hut of the deceased ${ }^{37}$. In winter trembita was also used during the rite of caroling, which may be connected with the transfer of this rite from the spring to winter period ${ }^{38}$.

The principle of playing trembita in specific times of the year is followed until today. Using the appropriate sound signals, the oldest and most important of shepherds (watah) convened shepherds for the morning, afternoon and evening milking ${ }^{39}$, signaled the moments of driving herds from pastures to the shelter, or informed about the predator attack on the herd. The signal played on trombita created a specific sign - informing about arriving at the the mountain meadow, about the need to summon shepherds to milking, or about the approaching danger. In the tradition of caroling the signal played on trembita creates a sign of the approaching group of carol singers, but also informs about the place of their current stay. The few references in research about the features of the instrument indicate mainly its signaling and communicative function. Oskár Elschek writes: "trembita was the signaling instrument of shepherds, who use for communication between shepherds huts, during grazing and to pass various information to the village" 40 .

The analysis of the interviews with Christmas carol singers in the Hutsul region made it possible to explore other non-signaling aspects of the instrument, namely: the magical function of trembita. The period of caroling, grazing, and weddings includes the most important days as far as the magical aspect is concerned, because all magical activities assure not only the success of caroling, grazing and the wedding rites, but also further existence of the people. Especially the caroling time (falling primarily in spring) and the grazing period are stigmatized in the traditional thinking by the features which are ontologically insecure. It is the result of the contact between the borders of two worlds: the domesticated and the unfamiliar one, the transition from the winter to spring, and the awakening of all forms of life. Contact with supernatural powers was possible in the empty spaces of pasture and the spaces through which the

\footnotetext{
${ }^{35}$ L. Kunz, Nástroje lidové hudby v Ćechách, na Moravě a ve Slezsku, vol. 3, Rožnov 2010, p. 597.

${ }^{36}$ W. Szuchiewicz, Huculszczyzna, Lwów 1902, vol. 2, p. 88.

37 Ibidem.

${ }^{38}$ J. Cząstka-Kłapyta, Kolędowanie, p. 418.

39 Б. Яремко, Трембита как феномен, р. 69.

${ }^{40}$ Trad. made by author of this article: O. Elschek, op. cit., p. 87.
} 
carol singers walked ${ }^{41}$, and because of the All Souls' Day-like character of carol singing. According to the Hutsul trembita players, the signals played by the instrument gave protection against unwanted powers and stimulated the fertility forces of nature. Hence trembita is mandatorily played in front of the church at the beginning and the end of the Rizdwa period (Christmas, January 7-19) at the graves (before and after the completion of carol singing), on the way home and when approaching it, in front of the house (before and after carol singing), during the performance of Christmas carols for the dead. Before World War II the tradition of trumpeting outside the house soon after the man's death was widespread ${ }^{42}$. During the funeral ceremony playing this instrument also falls on the moments of passage, when crossing the threshold of the house with the coffin, at the entrance to the cemetery, when crossing the bridge, on the approach to the tomb and finally when lowering the coffin down the grave $\mathrm{e}^{43}$.

The analysis of the function of trembita in the Hutsul caroling showed that until today its sounds form various figures of mediation via which it is possible to cross the boundaries between the worlds of the living and the realm of the sacred. According to the Hutsul beliefs the sounds of trembita allow them to reach the afterlife and the dead, from where the knowledge about the events of past and future and thereby the power to influence reality comes,.

The mediatory function of trembita is confirmed by the beliefs which still persist in the Hutsul oral tradition, and by the lyrics of the carols, which are a kind of a"Bible" and show trembita as an instrument related to the "other world", because it is played only by saints: George, Nicholas, Dmitri and God the Father himself (Hospod Boh), as well as Jesus Christ ${ }^{44}$.

In these carols the divine persons and the saints appear as trembita players who symbolically begin with the power of sounds new and qualitatively different sequences of time: spring (St. George), autumn (St. Dmitri), winter (St. Nicholas). Trembita sounds are heard in heavens by angels and the Virgin Mary, especially when they are played by Jesus Christ and God the Father. According to old beliefs, when trembita did not want to play, it meant that the soul of the deceased was burdened with too many sins and the way to heaven was closed for the dead ${ }^{45}$.

Another argument confirming the mediatory function of this instrument is the way in which trembita is produced. Hromovytsia wood obtained from a tree struck by lightning) from which trembita is construed expresses a deeper metaphorical content

41 P. Zając, O zaświatach niedalekich i cudach nadzwyczajnych. „,Nadprzyrodzone” w kulturze ludowej na przykładzie Huculszczyzny, Kraków 2004, p. 157-162.

42 The tradition known before World War II.

43 Personal field research, 2009, informant Jurij Tafijczuk (born. 1963 r., Bukowiec).

44 J. Cząstka-Kłapyta, Kolędowanie, p. 330.

${ }^{45}$ K. Kwiecień, Wędrówka po tym i tamtym Plaju. Problematyka przeznaczenia i losów duszy we współczesnych wyobrażeniach Hucułów. PHD thesis, Uniwersytet Jagielloński, Wydział Filozoficzny Instytut Religioznawstwa, Kraków 2010, p. 105. 
and metonymic bond ${ }^{46}$. It was previously thought that with the lightning a part of the voice of the first trembita Creator flowed down on the instrument ${ }^{47}$. The creator was a thunder deity associated with the celestial sphere. In the folk beliefs of ancient Slavs thunder deities, such as Zmij or Perun, were associated with the male organization of the universe and played an especially important role in maintaining life on earth, by protecting fertility, abundance and prosperity ${ }^{48}$. Therefore, fire protected people from all that is evil and dark, and in the form of lightning it struck most often in places where evil spirits dwelled. In this way such places, touched by the celestial force, were purified $^{49}$. The contact of spruce and the divine fire created a magical effect, because the magical principle stated that things that were once in contact with each other will remain connected forever ${ }^{50}$. That's why hromovytsia gained the cleansing and protective power of the sacred fire, which was then transferred to trembita. Dialogue with the celestial sphere is expressed in one of the statements: “(...) The sounds of trembita come out of her like 'the rays of sunshine' and meeting the real rays they talk to them as equals" 51 . The causative force of this instrument could also result from the magical properties attributed to the birch, whose bark obtained in the early spring was used to wrap the main body of the instrument. The birch was considered by the Slavs a sacred tree associated with fertility deities. It was also a symbol of the rebirth of life, a new cycle of vegetation, hence it was used as the main prop in the New Year celebration and in many ceremonies whose aim was stimulating the fertility of the earth and all beings ${ }^{52}$. Trembita was also used for the purposes of exorcism. It could also have non-musical functions of cleansing and protecting. It was used for magical purposes by molfars (sorcerers), who well knew the properties of hromovytsia and used it for love magic purposes and to protect livestock against charms. It was also a tool of negative magic, because if someone wanted to hurt someone's cow e.g. to cause its bloating and death, or make it give bad milk, he could catch a small trout in the creek and throw it into the fire through the trembita's pipe ${ }^{53}$. These facts indicate that this instrument can be regarded as an important tool of magic (positive and negative), which fulfilled protective, mediatory, life-stimulating and communicative functions in the pastoral tradition of grazing ${ }^{54}$. The sounds of this instrument during grazing could perform a similar function as during the caroling rites form a barrier against evil spir-

46 Gustav Juzala shows a similar bond in reference to bagpipes made of buckskin : G. Juzala, Semantyka kolęd wiosennych, Semantyka kolęd wiosennych. Studium, Warszawa 2012.

47 I. Macijewski, Huculska trembita, p. 77.

48 Ibidem, p. 39, 40.

49 Ibidem, p. 200.

${ }^{50}$ U. J. Krzywda, Magia z huculskich połonin, in: Huculszczyzna, jej kultura i badacze. Międzynarodowa konferencja naukowa w ramach Festiwalu Huculskiego „Za głosem trembity” 2006, J. Stęszewski, J. Cząstka-Kłapyta (ed.), Kraków 2008, p. 87.

51 I. Macijewski, Huculska trembita, p. 77.

52 P. Kowalski, Leksykon. Znaki Świata - omen, przesąd, znaczenie, Wrocław 1998, p. 34-36.

53 Personal field research, Bukowiec, 2010, informant trembitar Jurij Tafijczuk (born 1963).

54 P. Szekieryk-Donykiw, Dido Iwanczik, Werchowyna 2007, p. 350. 
its and charms, and stimulate vital forces ${ }^{55}$. Playing the instrument during grazing in the liminal moments, during sunrise, at noon, and dusk was probably associated with the protective function ${ }^{56}$. The signals of these instruments were sacralizing pastures, could protect animals and shepherds huts along with their personal belongings. In this way the "ritual clamour" was created. The clamour was necessary to awake the forces supporting this important moment of transition, especially during the so-called exit onto pastures (polonins'kiy khid). A similar function was known in other regions of the Carpathians, Podhale, during the so-called redyk and in the Silesian Beskids during combining the flocks (mishani). The "ritual clamour" was generated by other instruments such as pastoral bells hung around the necks of sheep, goats, horses and cows, or whips and guns, as well as singing and dancing. The magical function of sound which was produced not using trembita but also voice, is proved by the ban on whistling and singing, which was in force for shepherds during milking sheep to prevent wolves from attacking the flock.

Whistling was also not possible in the shepherds hut, because it could bring death upon someone from the hut ${ }^{57}$. Similarly, bad consequences resulted from the failure to comply with the ban on dancing and singing (the Eastern and Western Carpathians) in the hut until St. Johns day (24 June), and in the Eastern Carpathians until St. Peter and Paul day (July 11). Only in the Silesian Beskids it was allowed to a large village gathering on the first day of sheep flocks merging.

Finally, the question arises whether this persistent mediatory, communicative, and signaling function of trembita in the Hutsul region can be classified as a relic of the once broadly widespread pre-Christian beliefs associated with the underworld or a solar deity. It cannot be completely precluded that the beliefs came into the Northern and Eastern Carpathians along with the Vlach shepherds migrating to these regions. The role of music in the process of the direct transition to the sacred sphere proves that in some ways music is stronger than speech, independent of it, and functions as a sonic semiotic system.

The research problems outlined in this article, associated mainly with the magical function of the instrument should be considered also in the context of the field studies of the Vlachs colonization in the Balkans. Certainly, a separate, comparative study the pastoral signals played on trembita, would provide more conclusions. All the more so since the pilot research indicates that hat there are some sound structures played on this instrument which connect different parts of the Carpathians on the migration routes of the Vlachs ${ }^{58}$.

55 Ibidem.

56 Personal field research, Jasieniów 2010.

57 J. Cząstka-Kłapyta, Muzyczna kultura pasterska, p. 57.

58 A comparison of the signals played on trombita in Hutsul region (Ukraine), Bukovina (Romania) and in the mountainous regions of Transylvania (Romania) can serve as an example. 


\section{BIBLIOGRAPHY}

Alexandru Tiberiu, Romanian folk music, Bucharest 1980.

Boryś Wiesław, Kultura muzyczna dawnych Stowian w świetle stownictwa, [in:] Dzieje Stowian w świetle leksyki, red. Jerzy Rusek, Wiesław Boryś, Leszek Bednarczuk, Kraków 2002.

Chelcea Ion, Consideraţii etnografice cu privire la bucium, tulnic şi trâmbiţa, „Revista de Etnografie şi Folclor", 1989, vol 34, no 1, p. 59-65.

Chybiński Adolf, O Polskiej muzyce ludowej, Warszawa 1961.

Chybiński Adolf, O Polskiej muzyce ludowej, Warszawa 1961.

Cząstka-Kłapyta Justyna, Kolędowanie na Huculszczyźnie, Kraków 2013.

Cząstka-Kłapyta Justyna, Wplywy wołoskie w folklorze muzycznym Karpat ze szczególnym uwzględnieniem rusińskiej wsi Ostrunia - przyczynek do rozważań, [in:] Wołoskie Dziedzictwo Karpat, Czeski Cieszyn 2008.

Cząstka-Kłapyta Justyna, Muzyczna Kultura Pasterska, [in:] Pasterstwo w Karpatach. Tradycja i wspótczesność, red. Małgorzata Kiereś, Barbara Rosiek, Warszawa 2013.

Domaradzka-Barbier Aurélia, Praktyka muzyczna górali ślaskich: analiza śpiewów beskidzkich i próba wyodrębnienia modelu struktury melodycznej, „Muzyka”, 2001, no 3, p. 51-67.

Elscheková Alica, Stratigraphische Probleme der Volksmusik in den Karpaten und auf dem Balkan, Bratislva 1981.

Juzala Gustaw, Semantyka kolęd wiosennych. Studium, Warszawa 2012.

Kotoński Włodzimierz, Uwagi o muzyce Podhala, „Muzyka”, 1953, no 5-12.

Kotoński Włodzimierz, Uwagi o muzyce Podhala. „Muzyka”, 1954, no 5-6.

Kopoczek Alojzy, Ludowe instrumenty muzyczne polskiego obszaru karpackiego, Rzeszów 1996.

Kowalski Piotr, Leksykon. Znaki Świata - omen, przesą, znaczenie, Wrocław 1998.

Kresánek Jozef, Slovenská l'udová pieseň zo stanoviska hudobného, Bratislava 1997.

Kugutjak Mikołaj, Ternoszorskie skelne swiatliszcze w Karpatch, Iwano Frankiwsk 2007.

Kunz Ludvik, Nástroje lidové hudby v Ćechách, na Moravě a ve Slezsku, vol. 2, 4, Rožnov 2009-2010.

Kwiecień Karolina, Wędrówka po tym i tamtym Płaju. Problematyka przeznaczenia i losów duszy we współczesnych wyobrażeniach Hucułów. PhD thesis, Jagiellonian Univeristy, Faculty of Philosophy, Cracow 2010.

Macijewski Ihor, Muzyczni Instrumenty Huculiw (Музичні інструменти гуцулів), Winnycia (Вінниця) 2012.

Macijewski Ihor, Huculska trembita, [in:] Huculszczyzna, jej kultura i badacze. Międzynarodowa konferencja naukowa w ramach Festiwalu Huculskiego „Za głosem trembity”, 2006, eds. Jan Stęszewski, Justyna Cząstka-Kłapyta, Kraków 2008, s. 77.

Macijewski Ihor, Narodna instrumentalna kultura tradicyjnoj pochronnoj obriadnosti Huculiw, [in:] Czetwerta konferencja doslidnykiw narodnoj muzyky czerwonoruskych (halicko - wolodymyrskych) ta sumiżnych zemel, L'viv 1994.

Macijewski Ihor, Muzyka huculska w kontekście międzykulturowym [in:] Huculi, Bojkowie, Łemkowie. Tradycja i wspótczesność. Stanistaw Vincenz - po stronie dialogu. W 120.roczcnicę urodzin Stanisława Vincenza, red. Justyna Cząstka-Kłapyta, Kraków 2008.

Moszyński Kazimierz, Kultura Ludowa Stowian, vol. 2, Warszawa 1968, p. 591.

Szekieryk-Donykiw Petro, Dido Iwanczik, Werchowyna 2007.

Szekieryk-Donykiw Petro, Jak widbuwajut'sja koljdy u Huculiw, „Etnograficzny zbirnyk” (Lviv), 1914, vol. 35 .

Szuchiewicz Włodzimierz, Huculszczyzna, Lwów 1902, vol. 2, p. 88.

Winniczuk Lidia, Ludzie, zwyczaje i obyczaje starożytnej Grecji i Rzymu, Warszawa 2004.

Zając Paweł, O zaświatach niedalekich i cudach nadzwyczajnych. „Nadprzyrodzone” w kulturze ludowej na przyktadzie Huculszczyzny, Kraków 2004, s. 157-162.

Żerańska-Kominek Sławomira, Antropologiczne ujęcie problemu analizy muzycznej, „Muzyka”, 2000, no 4. 